\title{
Growth hormone and mild exercise in combination increases markedly muscle mass and tetanic tension in old rats
}

\author{
Niels Bechtold Andersen, Troels Torp Andreassen, Hans Ørskov ${ }^{1}$ and Hans Oxlund \\ Department of Connective Tissue Biology, Institute of Anatomy and ${ }^{1}$ Institute of Experimental Clinical Research, University of Aarhus, \\ DK-8000 Aarhus C, Denmark
}

(Correspondence should be addressed to H Oxlund, Department of Connective Tissue Biology, Institute of Anatomy, University of Aarhus, DK-8000 Aarhus C, Denmark; Email: ho@ana.au. dk)

\begin{abstract}
Objective: A decline of skeletal muscle mass and strength is seen with aging and immobilization. Growth hormone $(\mathrm{GH})$ has been shown to increase muscle mass. In the present study the effects of a combination of mild exercise and GH on skeletal musculature tetanic tension, dry defatted weight (DDW), volume, water, fat and collagen concentrations were investigated in old rats.

Design: Recombinant human GH (2.7 mg/kg per day) was injected subcutaneously for 73 days in 21 month-old female rats. Exercised rats ran on a treadmill, $8 \mathrm{~m} / \mathrm{min}$ for $1 \mathrm{~h} /$ day. The in vivo maximal tetanic tension of the calf musculature $(\mathrm{m}$. soleus, $\mathrm{m}$. plantaris, $\mathrm{m}$. gastrocnemius together) was analysed in anaesthetized rats by stimulating the ischiadic nerve.

Results: The maximal tetanic tension was increased by $23 \%$ in GH-injected compared to saline-injected rats. Mild exercise $+\mathrm{GH}$ in combination resulted in a further $18 \%$ increase in maximal tetanic tension. The mild exercise by itself did not influence the maximal tetanic tension significantly when compared with saline injected rats. The GH administration and/or mild exercise did not change skeletal muscle endurance, measured as tetanic tension during $30 \mathrm{~s}$ of stimulation. Serum IGF-I concentration was increased twofold in GH-injected rats.

Conclusion: The increased muscle mass induced by $\mathrm{GH}+$ mild exercise was associated with a corresponding increase in maximal tetanic tension. Combination of $\mathrm{GH}+$ mild exercise resulted in a substantial further increase of muscle mass and maximal tension compared with GH injections alone in these old rats.
\end{abstract}

European Journal of Endocrinology 143 409-418

\section{Introduction}

Weakening of skeletal musculature in relation to aging and immobilization has become a major health problem, especially the often fatal interaction between muscle weakness and osteoporosis. Growth hormone (GH) administration may have anabolic effects on both skeletal musculature and bone in humans (1). In old subjects, GH increased muscle mass and strength, but did not restore the rate of myofibrillar protein synthesis (2). In animal studies higher doses of GH and two injections per day of $\mathrm{GH}$ have been shown to increase both muscle mass and bone mass markedly in old rats (3), but it has not been investigated whether the increase in muscle mass after $\mathrm{GH}$ administration is associated with a corresponding increase in muscle strength. GH has pronounced effects on skeletal muscle cell proliferation and growth $(4,5)$ and the skeletal muscle fiber types do not change in GH-injected rats (6). Furthermore, there seems to be an interaction on muscle mass when $\mathrm{GH}$ administration is combined with exercise (7). The decrease in protein synthesis in $\mathrm{m}$. gastrocnemius seen after hindlimb suspension of rats was reduced when $\mathrm{GH}$ administration and exercise were combined, but no effect was seen with either GH administration or exercise alone (8). In some human studies, however, GH + exercise was no more effective than exercise without GH supplementation at increasing muscle mass and maximal voluntary muscle strength $(9-11)$. No increase in the rate of muscle protein synthesis of weight lifters (12), and no changes in muscle tissue GH receptor-, insulin-like growth factor-I (IGF-I)-, or IGF-I receptor mRNA of exercising elderly men were found after treatment with GH (13). Therefore, further studies are required to clarify the interaction between $\mathrm{GH}$ administration and exercise on muscle strength.

The aim of this study was to investigate the effect of $\mathrm{GH}$ administration in old rats. The primary aim was to investigate whether the expected increase in muscle 
mass was associated with changes in muscle strength. The effect of combining $\mathrm{GH}$ with mild exercise was also studied.

\section{Materials and methods}

The study was approved by the Danish Animal Experimental Inspectorate. Seventy-three female Wistar rats, 18 months old, were randomly divided into five groups, with 14-15 rats in each group. The start control group (Group 1) was killed at the beginning of the experiment. Groups 2-5 were all injected twice daily in the nape of the neck for 73 days, Groups 2 and 3 with isotonic sodium chloride and Groups 4 and 5 with recombinant human $\mathrm{GH}$ (Norditropin; Novo Nordisk A/S, Gentofte, Denmark, specificity $1 \mathrm{mg}=3 \mathrm{IU}$ ) at a dose of $2.7 \mathrm{mg} / \mathrm{kg}$ per day. Furthermore, Groups 3 and 5 were exercised mildly on a treadmill ( 5 days a week, $1 \mathrm{~h} /$ day, $8 \mathrm{~m} / \mathrm{min}$ ). The rats were caged separately under conditions of $12 \mathrm{~h}$ light: $12 \mathrm{~h}$ dark and had free access to tap water and pellet food.

Based on Klitgaard et al. (14), the in vivo maximal tetanic tension and time course of the tetanic tension of $\mathrm{m}$. soleus, $\mathrm{m}$. plantaris and $\mathrm{m}$. gastrocnemius together were studied in anaesthetized rats (pentobarbital $60 \mathrm{mg} / \mathrm{kg}$ i. p. ). The proximal end of the three muscles was fixed by a $0.7 \mathrm{~mm}$ steel wire (Dentarum, nr 528-070-00, Scanorto, Hellerup, Denmark) through a 1-mm transversal canal drilled through the center of the femur epicondyles. The tendons of the three muscles were fixed with a pean to help retain their natural in situ length, and the calcaneus was then cut and the distal end of the tendons clamped and fixed to the moveable crosshead of a materials testing machine. The femur epicondyles were fixed by the steel wire to the strain gauge of the materials testing machine (TCT5, Lorentzen \& Wettre, Stockholm, Sweden). The isometric muscle tension was measured continuously by means of a load strain gauge and a measuring bridge, and the direct signal fed to an X-t recorder (Philips PM 8272, XYt recorder).

The muscles were stimulated to contraction through the $\mathrm{n}$. ischiadicus on the back of the thigh. The electrical stimuli were given through steel electrodes (diameter $1.2 \mathrm{~mm}$, electrode distance $1 \mathrm{~mm}$ ) which were connected to a stimulator (Anapulse stimulator, model 302-T, W-P Instruments, New Haven, CT, USA). The electrodes were isolated from the surrounding tissue with parafilm (American National Can/Greenwich, USA) to avoid activation of adjacent muscles and nerves. During the experiment the rats were placed on a small electric blanket to maintain a constant body temperature.

At the beginning of the experiment the muscles were strained to a tension of $4 \mathrm{~N}$. The first two stimulations (single) were $30 \mathrm{~V}$ for $4 \mathrm{~ms}$, and were given to confirm that the location of the electrodes was correct. The next two stimulations were of $1 \mathrm{~s}$ duration at $30 \mathrm{~V}$, with an impulse duration of $4 \mathrm{~ms}$ and a frequency of $100 \mathrm{~Hz}$, resulting in maximal tetanic contraction. The last stimulation was of $30 \mathrm{~s}$ duration at $30 \mathrm{~V}$, impulse duration of $4 \mathrm{~ms}$ and a frequency $100 \mathrm{~Hz}$. The maximal tetanic tension was defined as the mean value of the maximal tetanic tension obtained in the last three contractions. The endurance of the muscles was studied by following the time course of the tetanic tension during the 30 seconds of stimulation.

Preliminary studies showed no difference in muscle twitch tension at pre-strain values between 3 and $5 \mathrm{~N}$ and therefore, we chose a muscle tension level of $4 \mathrm{~N}$. Concerning voltage levels, the muscle twitch tension was significantly lower at $7.5 \mathrm{~V}$ compared with higher voltage levels. No difference was observed between muscle twitch tensions induced at 15-95 V. We chose $30 \mathrm{~V}$ to obtain the maximal stimulation level. Furthermore, preliminary studies showed no difference in the muscle twitch tension of the right and left leg of the animals.

The anaesthetized rats were killed by exsanguination. Five muscles were dissected free from the right hind leg: $m$. soleus; $m$. plantaris; $m$. gastrocnemius; $m$. tibialis anterior; and $\mathrm{m}$. extensor digitorum longus, listed according to their relative content of type I fibers (15). The wet weight (WW) of each of the five muscles was measured immediately after removal. The muscles were placed into a Ringer's solution and submitted to vacuum (200 torr) for $10 \mathrm{~min}$ in a rotary evaporation system (Hetovac; Heto, Allerød, Denmark) in order to remove trapped air bubbles. The muscle weight when submerged in Ringer's solution was recorded $(\mu \mathrm{S})$.

The muscle volume $(\mathrm{V})$ was calculated from the equation $\mathrm{V}=(\mathrm{WW}-\mu \mathrm{S}) / \rho \mathrm{H}_{2} \mathrm{O}$, where $\rho \mathrm{H}_{2} \mathrm{O}$ is the density of water. The muscles were then freeze-dried for 7 days and weighed (dry weight $=D W)$. The water content was calculated as WW-DW. The muscles were defatted for 7 days in three changes of acetone, freezedried for 3 days and weighed to give the dry defatted weight (DDW). The muscle density was calculated as DDW/V. The tibia bone length was measured from facies articularis condylus medialis to facies articularis inferior with a sliding caliper.

\section{Determination of hydroxyproline}

The tendons and aponeuroses were removed from the muscles using a scalpel. Biopsies $(2 \times 2 \times 2 \mathrm{~mm})$ were cut from each of four muscles (m. soleus, m. plantaris, $\mathrm{m}$. tibialis anterior and $\mathrm{m}$. extensor digitorum longus) defatted, freeze-dried, weighed and hydrolysed in $6 \mathrm{M} \mathrm{HCl}$ for determination of the concentration of hydroxyproline (16).

\section{Determination of IGF-I}

Total serum IGF-I was measured by a RIA technique according to Flyvbjerg \& Ørskov (17). 


\section{Statistical analyses}

For analysis of differences between the groups, the Kruskal-Wallis test was used, and in cases where differences occurred, the Mann-Whitney U-test was applied (18). $P<0.05$ (two-tailed) was considered statistically significant.

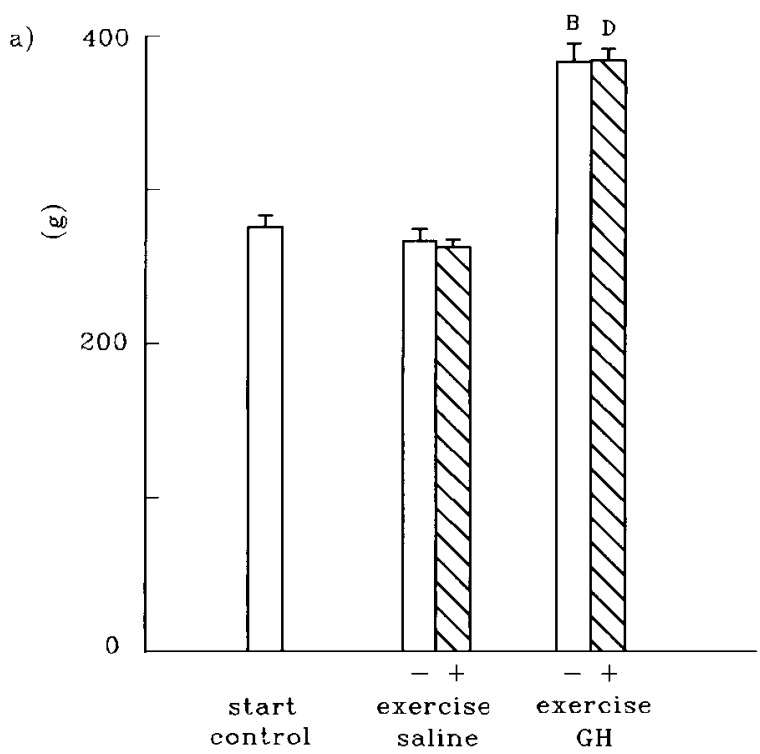

b)

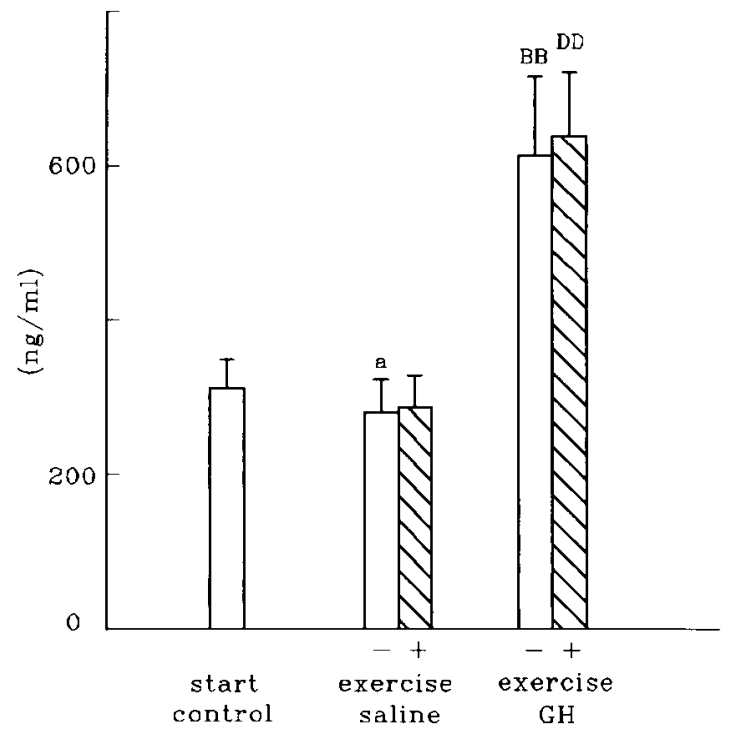

Figure 1 End body weight (a) and serum IGF-I (b). Mean values with S.E.M. are given for the start control group, groups injected with saline, exercised, injected with growth hormone $(\mathrm{GH})$, and exercised+injected with $\mathrm{GH}$ daily for 73 days. Exercised groups are delineated by hatched bars, and groups without exercise by open bars. a, $P \leq 0.05$ against start control; $\mathrm{B}, P \leq 0.001$;

$\mathrm{BB}, P \leq 0.0001$ against saline; $\mathrm{D}, P \leq 0.001 ; \mathrm{DD}, P \leq 0.0001$ against exercise.

\section{Results}

\section{The effects of GH administration}

GH administration for 73 days increased the body weight $(43 \%)$ of the rats compared to the saline-injected group (Fig. 1a). Serum IGF-I was increased twofold
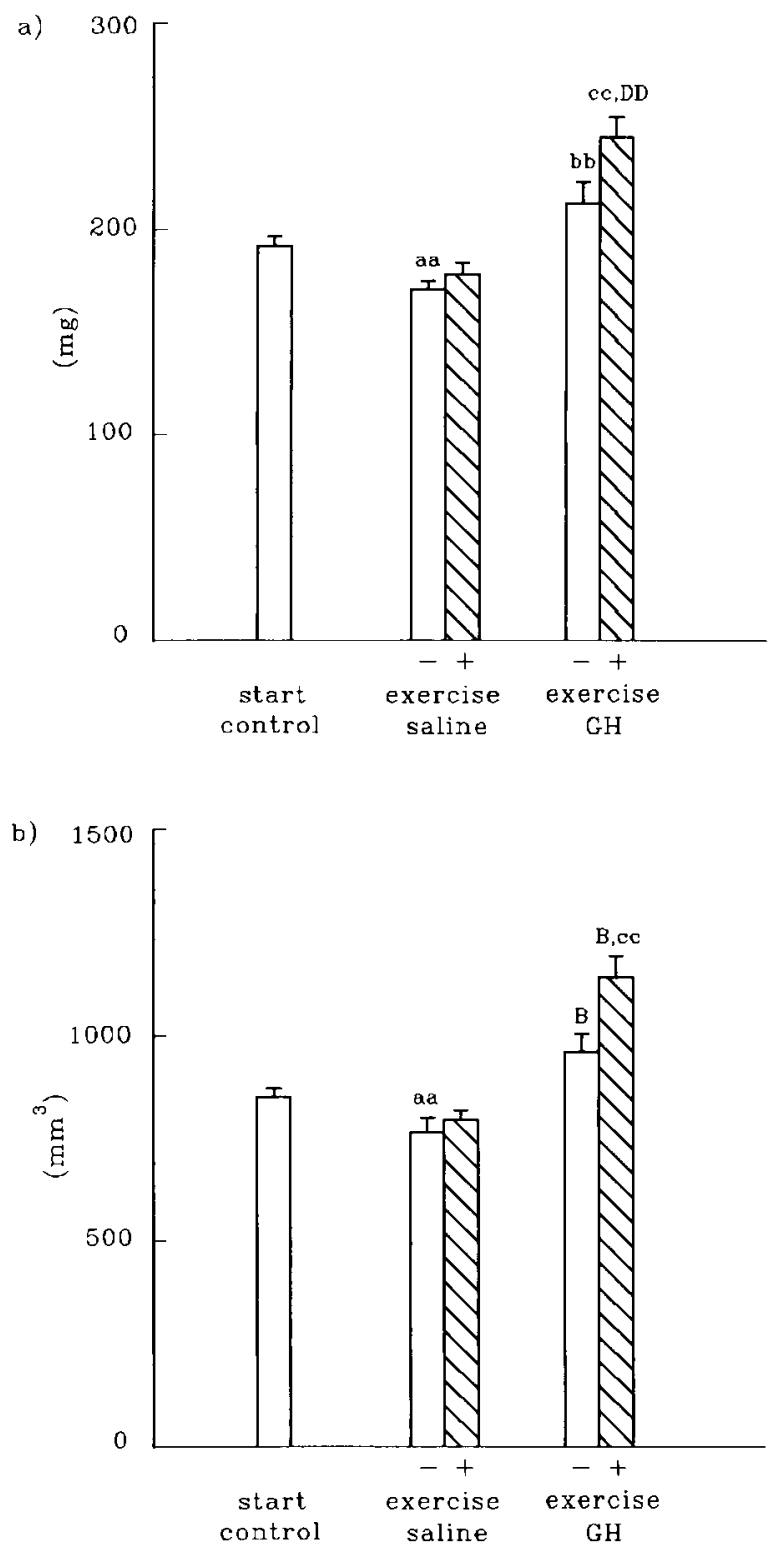

Figure 2 Muscle mass dry defatted weight (a) and volume (b) of $\mathrm{m}$. gastrocnemius from old rats. Mean values with S.E.M. are given for the start control group, groups injected with saline, exercised, injected with growth hormone (GH), and exercised+injected with $\mathrm{GH}$ daily for 73 days. Exercised groups are delineated by hatched bars, and groups without exercise by open bars. aa, $P \leq 0.01$ against start control; bb, $P \leq 0.01 ; \mathrm{B}, P \leq 0.001$ against saline; $\mathrm{DD}, P \leq 0.0001$ against exercise; $\mathrm{cc}, P \leq 0.01$ against $\mathrm{GH}$ alone. 
compared to the saline control group (Fig. 1b). The muscle mass (measured as DDW) and volume was increased in the group administered GH (25-50\%) compared with the saline-injected group (Fig. 2, Table 1). The tibia length was increased by $6 \%$ compared with the saline-injected group (Table 2). The relative content of fat was reduced in all muscles from GH-treated rats compared to those treated with saline. On the other hand, the relative water content in the muscles was increased in the five muscles, but not significantly in $\mathrm{m}$. tibialis anterior in $\mathrm{GH}$-injected rats compared to saline-injected rats. The muscle density calculated as DDW/volume did not show any difference between the $\mathrm{GH}$-injected and the saline-injected rats (Table 1). The hydroxyproline concentration was increased in $\mathrm{m}$. extensor digitorum longus in the $\mathrm{GH}-$ injected group; however, the hydroxyproline concentration in the $\mathrm{m}$. soleus, $\mathrm{m}$. plantaris and $\mathrm{m}$. tibialis anterior was not significantly different from the saline-injected rats (Table 3 ).

The maximal tetanic tension of $\mathrm{m}$. plantaris, $\mathrm{m}$. soleus and $\mathrm{m}$. gastrocnemius together was increased by $23 \%$ in the $\mathrm{GH}$-injected group compared to the saline-injected group (Fig. 3a, Table 2). The maximal

Table 1 Dry defatted weight, water and fat content, volume and density of skeletal muscles from old rats injected with GH and exercised. Muscles are listed according to relative content of red fibres (15).

\begin{tabular}{|c|c|c|c|c|c|c|}
\hline & $\begin{array}{l}\text { A: Start } \\
\text { control }\end{array}$ & B: Saline & C: GH & $\begin{array}{l}\text { D: Saline + } \\
\text { exercise }\end{array}$ & $\begin{array}{l}\text { E: GH + } \\
\text { exercise }\end{array}$ & $\begin{array}{c}\text { Kruskal- } \\
\text { Wallis } \\
P \text { value }\end{array}$ \\
\hline \multicolumn{7}{|l|}{ M. soleus } \\
\hline $\begin{array}{l}\text { Dry defatted weight }(\mathrm{mg}) \\
\text { Water content }(\%) \\
\text { Fat content }(\%) \\
\text { Volume }\left(\mathrm{mm}^{3}\right) \\
\text { Density }\left(10^{-2} \mathrm{mg} / \mathrm{mm}^{3}\right)\end{array}$ & $\begin{array}{l}13.8 \pm 0.3 b b \\
77.8 \pm 0.5 \\
17.5 \pm 0.7 \\
72.9 \pm 2.2 b b \\
19.0 \pm 0.4\end{array}$ & $\begin{array}{l}12.5 \pm 0.3 \\
77.3 \pm 0.2 \\
16.7 \pm 1.3 \\
63.7 \pm 1.9 \\
19.7 \pm 0.4\end{array}$ & $\begin{array}{l}18.9 \pm 0.6 \mathrm{~A}, \mathrm{~B}, \mathrm{D} \\
78.6 \pm 0.4 \mathrm{~d}, \mathrm{bb} \\
11.8 \pm 0.8 \mathrm{~A}, \mathrm{bb}, \mathrm{D} \\
96.3 \pm 3.3 \mathrm{~A}, \mathrm{~B}, \mathrm{D} \\
19.7 \pm 0.3\end{array}$ & $\begin{array}{l}14.1 \pm 0.2 \mathrm{~B} \\
77.4 \pm 0.4 \\
17.7 \pm 1.1 \\
73.3 \pm 1.1 \mathrm{~B} \\
19.3 \pm 0.3\end{array}$ & $\begin{aligned} 22.5 & \pm 0.6 \mathrm{~A}, \mathrm{~B}, \mathrm{C}, \mathrm{D} \\
79.3 & \pm 0.2 \mathrm{aa}, \mathrm{B}, \mathrm{D} \\
9.8 & \pm 0.5 \mathrm{~A}, \mathrm{~B}, \mathrm{D} \\
115.8 & \pm 3.2 \mathrm{~A}, \mathrm{~B}, \mathrm{C}, \mathrm{D} \\
19.5 & \pm 0.2\end{aligned}$ & $\begin{array}{l}P<0.001 \\
P<0.001 \\
P<0.001 \\
P<0.001 \\
P=0.506\end{array}$ \\
\hline \multicolumn{7}{|l|}{ M. plantaris } \\
\hline $\begin{array}{l}\text { Dry defatted weight }(\mathrm{mg}) \\
\text { Water content }(\%) \\
\text { Fat content }(\%) \\
\text { Volume }\left(\mathrm{mm}^{3}\right) \\
\text { Density }\left(10^{-2} \mathrm{mg} / \mathrm{mm}^{3}\right)\end{array}$ & $\begin{aligned} 36.3 & \pm 0.9 \\
79.5 & \pm 0.3 \\
6.9 & \pm 0.6 \\
180 & \pm 4 \\
20.2 & \pm 0.2\end{aligned}$ & $\begin{aligned} 34.0 & \pm 0.8 \\
79.1 & \pm 0.2 \\
8.2 & \pm 0.6 \\
168 & \pm 4 \\
20.2 & \pm 0.2\end{aligned}$ & $\begin{array}{c}45.5 \pm 2.4 \mathrm{aa}, \mathrm{B}, \mathrm{D} \\
80.1 \pm 0.2 \mathrm{a}, \mathrm{bb}, \mathrm{d} \\
4.7 \pm 0.4 \mathrm{aa}, \mathrm{B}, \mathrm{dd} \\
228 \pm 11 \mathrm{~A}, \mathrm{~B}, \mathrm{D} \\
19.9 \pm 0.2\end{array}$ & $\begin{aligned} 34.0 & \pm 1.3 \\
79.6 & \pm 0.2 \\
6.9 & \pm 0.4 \\
170 & \pm 5 \\
20.0 & \pm 0.2\end{aligned}$ & $\begin{aligned} & 49.1 \pm 1.5 \mathrm{~A}, \mathrm{~B}, \mathrm{D} \\
& 80.2 \pm 0.3 \mathrm{bb}, \mathrm{d} \\
& 3.9 \pm 0.4 \mathrm{~A}, \mathrm{~B}, \mathrm{D} \\
& 243 \pm 7 \mathrm{~A}, \mathrm{~B}, \mathrm{D} \\
& 20.2 \pm 0.2\end{aligned}$ & $\begin{array}{l}P<0.001 \\
P=0.007 \\
P<0.001 \\
P<0.001 \\
P=0.759\end{array}$ \\
\hline \multicolumn{7}{|l|}{ M. gastrocnemius } \\
\hline $\begin{array}{l}\text { Dry defatted weight }(\mathrm{mg}) \\
\text { Water content }(\%) \\
\text { Fat content }(\%) \\
\text { Volume }\left(\mathrm{mm}^{3}\right) \\
\text { Density }\left(10^{-2} \mathrm{mg} / \mathrm{mm}^{3}\right)\end{array}$ & $\begin{aligned} 192 & \pm 5 b b \\
77.5 & \pm 0.1 \\
5.1 & \pm 0.3 \\
851 & \pm 20 \mathrm{bb} \\
22.5 & \pm 0.1\end{aligned}$ & $\begin{aligned} 171 & \pm 4 \\
77.5 & \pm 0.1 \\
5.5 & \pm 0.2 \\
763 & \pm 15 \\
22.4 & \pm 0.1\end{aligned}$ & $\begin{aligned} 213 & \pm 10 \mathrm{bb}, \mathrm{dd} \\
78.2 & \pm 0.1 \mathrm{~A}, \mathrm{bb}, \mathrm{dd} \\
4.0 & \pm 0.2 \mathrm{aa}, \mathrm{B}, \mathrm{dd} \\
960 & \pm 43 \mathrm{a}, \mathrm{B}, \mathrm{dd} \\
22.2 & \pm 0.1\end{aligned}$ & $\begin{aligned} 178 & \pm 6 \mathrm{a} \\
77.7 & \pm 0.1 \\
5.2 & \pm 0.3 \\
795 & \pm 23 \\
22.3 & \pm 0.1\end{aligned}$ & $\begin{aligned} 245 & \pm 10 \mathrm{~A}, \mathrm{~B}, \mathrm{c}, \mathrm{D} \\
78.8 & \pm 0.5 \mathrm{~A}, \mathrm{~B}, \mathrm{D} \\
3.1 & \pm 0.2 \mathrm{~A}, \mathrm{~B}, \mathrm{CC}, \mathrm{D} \\
1140 & \pm 53 \mathrm{~A}, \mathrm{~B}, \mathrm{CC}, \mathrm{D} \\
21.7 & \pm 0.5\end{aligned}$ & $\begin{array}{l}P<0.001 \\
P<0.001 \\
P<0.001 \\
P<0.001 \\
P<0.117\end{array}$ \\
\hline \multicolumn{7}{|l|}{ M. tibialis anterior } \\
\hline $\begin{array}{l}\text { Dry defatted weight }(\mathrm{mg}) \\
\text { Water content }(\%) \\
\text { Fat content }(\%) \\
\text { Volume }\left(\mathrm{mm}^{3}\right) \\
\text { Density }\left(10^{-2} \mathrm{mg} / \mathrm{mm}^{3}\right)\end{array}$ & $\begin{array}{l}82.5 \pm 2.3 b b \\
78.5 \pm 0.2 \\
6.8 \pm 0.3 b \\
391 \pm 10 b b \\
21.1 \pm 0.2\end{array}$ & $\begin{aligned} 74.4 & \pm 1.6 \\
78.6 & \pm 0.3 \\
8.0 & \pm 0.3 \\
358 & \pm 6 \\
20.8 & \pm 0.3\end{aligned}$ & $\begin{aligned} 105.9 & \pm 3.6 \mathrm{~A}, \mathrm{~B}, \mathrm{D} \\
78.9 & \pm 0.2 \\
4.1 & \pm 0.2 \mathrm{~A}, \mathrm{~B}, \mathrm{D} \\
495 & \pm 16 \mathrm{~A}, \mathrm{~B}, \mathrm{D} \\
21.4 & \pm 0.2\end{aligned}$ & $\begin{aligned} 77.8 & \pm 1.8 \\
78.6 & \pm 0.2 \\
6.7 & \pm 0.2 \mathrm{bb} \\
369 & \pm 7 \\
21.1 & \pm 0.2\end{aligned}$ & $\begin{aligned} 109.0 & \pm 2.4 A, B, D \\
79.2 & \pm 0.2 \\
3.6 & \pm 0.2 A, B, D \\
514 & \pm 14 A, B, D \\
21.2 & \pm 0.2\end{aligned}$ & $\begin{array}{l}P<0.001 \\
P=0.233 \\
P<0.001 \\
P<0.001 \\
P=0.453\end{array}$ \\
\hline \multicolumn{7}{|c|}{ M. extensor digitorum longus } \\
\hline $\begin{array}{l}\text { Dry defatted weight }(\mathrm{mg}) \\
\text { Water content }(\%) \\
\text { Fat content }(\%) \\
\text { Volume }\left(\mathrm{mm}^{3}\right) \\
\text { Density }\left(10^{-2} \mathrm{mg} / \mathrm{mm}^{3}\right)\end{array}$ & $\begin{array}{l}18.7 \pm 0.6 \mathrm{bb} \\
79.0 \pm 0.2 \\
7.6 \pm 0.5 \\
92.1 \pm 2.8 \mathrm{~B} \\
20.4 \pm 0.3\end{array}$ & $\begin{array}{r}16.3 \pm 0.5 \\
78.4 \pm 0.3 \\
8.6 \pm 0.7 \\
79.0 \pm 2.4 \\
20.6 \pm 0.3\end{array}$ & $\begin{aligned} 20.6 & \pm 0.9 \mathrm{~B}, \mathrm{D} \\
79.7 & \pm 0.2 \mathrm{a}, \mathrm{B}, \mathrm{dd} \\
4.6 & \pm 0.6 \mathrm{aa}, \mathrm{B}, \mathrm{D} \\
101.3 & \pm 4.1 \mathrm{~B}, \mathrm{D} \\
20.3 & \pm 0.2\end{aligned}$ & $\begin{array}{c}16.7 \pm 0.4 \mathrm{aa} \\
78.6 \pm 0.4 \\
8.6 \pm 0.7 \\
81.6 \pm 1.5 \mathrm{aa} \\
20.4 \pm 0.3\end{array}$ & $\begin{aligned} 22.6 & \pm 0.9 \mathrm{aa}, \mathrm{B}, \mathrm{D} \\
79.6 & \pm 0.3 \mathrm{bb} \\
3.9 & \pm 0.3 \mathrm{~A}, \mathrm{~B}, \mathrm{D} \\
109.9 & \pm 4.2 \mathrm{aa}, \mathrm{B}, \mathrm{D} \\
20.6 & \pm 0.3\end{aligned}$ & $\begin{array}{l}P<0.001 \\
P<0.005 \\
P<0.001 \\
P<0.001 \\
P=0.723\end{array}$ \\
\hline
\end{tabular}

Means \pm S.E.M

Saline, Saline injections; GH, Growth hormone injections; Density, Dry defatted weight/Volume

a, $P<0.05$; aa, $P<0.01$. A, $P<0.001$, against the Start control group

b, $P<0.05$; bb, $P<0.01$. B, $P<0.001$, against the Saline group

c, $P<0.05$; cc, $P<0.01$. C, $P<0.001$, against the $\mathrm{GH}$ group

d, $P<0.05$; dd, $P<0.01$. D, $P<0.001$, against the Saline + exercise group 
Table 2 In vivo maximal tetanic tension (MTT) of calf musculature (m. soleus, $\mathrm{m}$. plantaris and $\mathrm{m}$. gastrocnemius together).

\begin{tabular}{|c|c|c|c|c|c|c|}
\hline & A: Start control & B: Saline & C: GH & $\begin{array}{c}\text { D: Saline + } \\
\text { exercise }\end{array}$ & $\begin{array}{l}\text { E: GH + } \\
\text { exercise }\end{array}$ & $\begin{array}{l}\text { Kruskal- } \\
\text { Wallis } \\
P \text { value }\end{array}$ \\
\hline $\begin{array}{l}\text { MTT }(\mathrm{N}) \\
\text { MTT/DDW }\left(10^{-3} \mathrm{~N} / \mathrm{mg}\right) \\
\text { Dry defatted weight }(\mathrm{mg}) \\
\text { Tibia length }(\mathrm{mm})\end{array}$ & $\begin{array}{l}15.9 \pm 0.6 \mathrm{~B} \\
65.4 \pm 3.0 \\
242 \pm 5 \mathrm{~B} \\
36.4 \pm 0.1\end{array}$ & $\begin{array}{l}13.2 \pm 0.2 \\
61.0 \pm 1.1 \\
218 \pm 4 \\
36.2 \pm 0.2\end{array}$ & $\begin{array}{l}16.2 \pm 1.0 \mathrm{~b}, \mathrm{~d} \\
58.1 \pm 1.9 \\
277 \pm 12 \mathrm{a}, \mathrm{B} \\
38.5 \pm 0.2 \mathrm{~A}, \mathrm{~B}, \mathrm{D}\end{array}$ & $\begin{aligned} 13.9 & \pm 0.5 \mathrm{a} \\
61.7 & \pm 1.9 \\
226 & \pm 7 \mathrm{a}, \mathrm{cc} \\
36.3 & \pm 0.1\end{aligned}$ & $\begin{aligned} 19.0 & \pm 0.9 \text { aa, B, c, D } \\
60.0 & \pm 1.5 \\
308 & \pm 10 \mathrm{~A}, \mathrm{~B}, \mathrm{D} \\
39.0 & \pm 0.2 \mathrm{~A}, \mathrm{~B}, \mathrm{D}\end{aligned}$ & $\begin{array}{l}P<0.001 \\
P=0.175 \\
P<0.001 \\
P<0.001\end{array}$ \\
\hline
\end{tabular}

Means \pm S.E.M

Saline, Saline injections; $\mathrm{GH}$, Growth hormone injections

a, $P<0.05$; aa, $P<0.01 ; \mathrm{A}, P<0.001$, against the Start control group

b, $P<0.05$; $\mathrm{B}, P<0.001$, against the Saline group

c, $P<0.05$; cc, $P<0.01$, against the GH group

d, $P<0.05 ; P<0.001$, against the Saline + exercise group

tetanic tension/mg DDW and the tetanic tension during $30 \mathrm{~s}$ of stimulation did not differ in the $\mathrm{GH}-\mathrm{injected}$ and the saline-injected animals (Figs $3 \mathrm{~b}$ and 4, Tables 2 and 4).

\section{The effect of exercise}

No difference was observed in the body weight of the exercised and the saline-injected groups (Fig. 1a). Serum IGF-I was not changed significantly compared to the saline group (Fig. 1b). The volume and DDW of the $\mathrm{m}$. soleus increased by $15 \%$ and $11 \%$ in the exercised group compared to the saline group; the exercised group showed no other changes in volume and DDW compared to the saline-injected group (Table 1). No difference in the tibia length of the exercised and the saline-injected group was seen (Table 2). The relative content of fat in $\mathrm{m}$. tibialis anterior was decreased in the exercised group versus the saline-injected group. In the other four muscles no significant changes were seen. No difference in the relative water content and the muscle density between the exercised group and the saline-injected group was observed (Table 1). The hydroxyproline concentration of m. soleus was increased after the 73 days of exercise compared with the saline-injected group (Table 3 ).

There was no difference in maximal tetanic tension in the exercised rats compared to the saline-injected rats. No difference was seen in maximal tetanic tension $/ \mathrm{mg}$ DDW or tetanic tension during 30 s of stimulation in the exercised and the saline-injected groups (Figs 3 and 4, Tables 2 and 4).

\section{The effects of GH administration and exercise in combination}

The final body weight and serum IGF-I of the GHinjected group and the GH-injected + exercised group were not different (Fig. 1). The volume and DDW of $\mathrm{m}$. soleus and $\mathrm{m}$. gastrocnemius were significantly increased $(15-20 \%)$ in the GH-injected + exercise rats versus the rats injected with $\mathrm{GH}$ alone (Fig. 2). No significant difference was seen in the muscle volume and DDW of $\mathrm{m}$. tibialis anterior, m. extensor digitorum longus and $\mathrm{m}$. plantaris (Table 1). There was no difference in the length of tibia (Table 2), the relative water content and the muscle density. A decrease in the relative fat content of the $\mathrm{GH}$-injected + exercised rats

Table 3 Hydroxyproline concentration of skeletal muscles ( $\mathrm{mg} / \mathrm{g}$ muscle tissue). Muscles are listed according to relative content of red fibres (Armstrong et al. (15)).

\begin{tabular}{|c|c|c|c|c|c|c|}
\hline & A: Start control & B: Saline & C: $\mathbf{G H}$ & $\begin{array}{c}\text { D: Saline + } \\
\text { exercise }\end{array}$ & $\begin{array}{l}\text { E: GH + } \\
\text { exercise }\end{array}$ & $\begin{array}{c}\text { Kruskal- } \\
\text { Wallis } \\
P \text { value }\end{array}$ \\
\hline M. soleus & $6.2 \pm 0.2 b$ & $7.1 \pm 0.3$ & $7.3 \pm 0.3 \mathrm{a}$ & $8.3 \pm 0.4 \mathrm{~A}, \mathrm{~b}$ & $7.5 \pm 0.3 \mathrm{aa}$ & $P<0.001$ \\
\hline M. plantaris & $4.5 \pm 0.2$ & $5.1 \pm 0.2$ & $5.6 \pm 0.5$ & $5.2 \pm 0.3$ & $5.4 \pm 0.3$ & $P=0.168$ \\
\hline M. tibialis anterior & $4.9 \pm 0.2$ & $5.3 \pm 0.2$ & $5.1 \pm 0.1$ & $5.2 \pm 0.2$ & $5.0 \pm 0.1$ & $P=0.062$ \\
\hline $\begin{array}{l}\text { M. extensor digitorum } \\
\text { longus }\end{array}$ & $5.7 \pm 0.3 b$ & $7.0 \pm 0.6$ & $8.6 \pm 0.5 \mathrm{~A}, \mathrm{bb}, \mathrm{D}$ & $6.3 \pm 0.3$ & $7.3 \pm 0.4 \mathrm{~A}, \mathrm{c}, \mathrm{d}$ & $P<0.001$ \\
\hline
\end{tabular}

Means \pm S.E.M.

Saline, Saline injections; $\mathrm{GH}$, Growth hormone injections

a, $P<0.05$; aa, $P<0.01$; A, $P<0.001$, against the Start control group

b, $P<0.05$; bb, $P<0.01$, against the Saline group

c, $P<0.05$; against the $\mathrm{GH}$ group

d, $P<0.05 ; \mathrm{D}, P<0.001$, against the Saline + exercise group 
a)
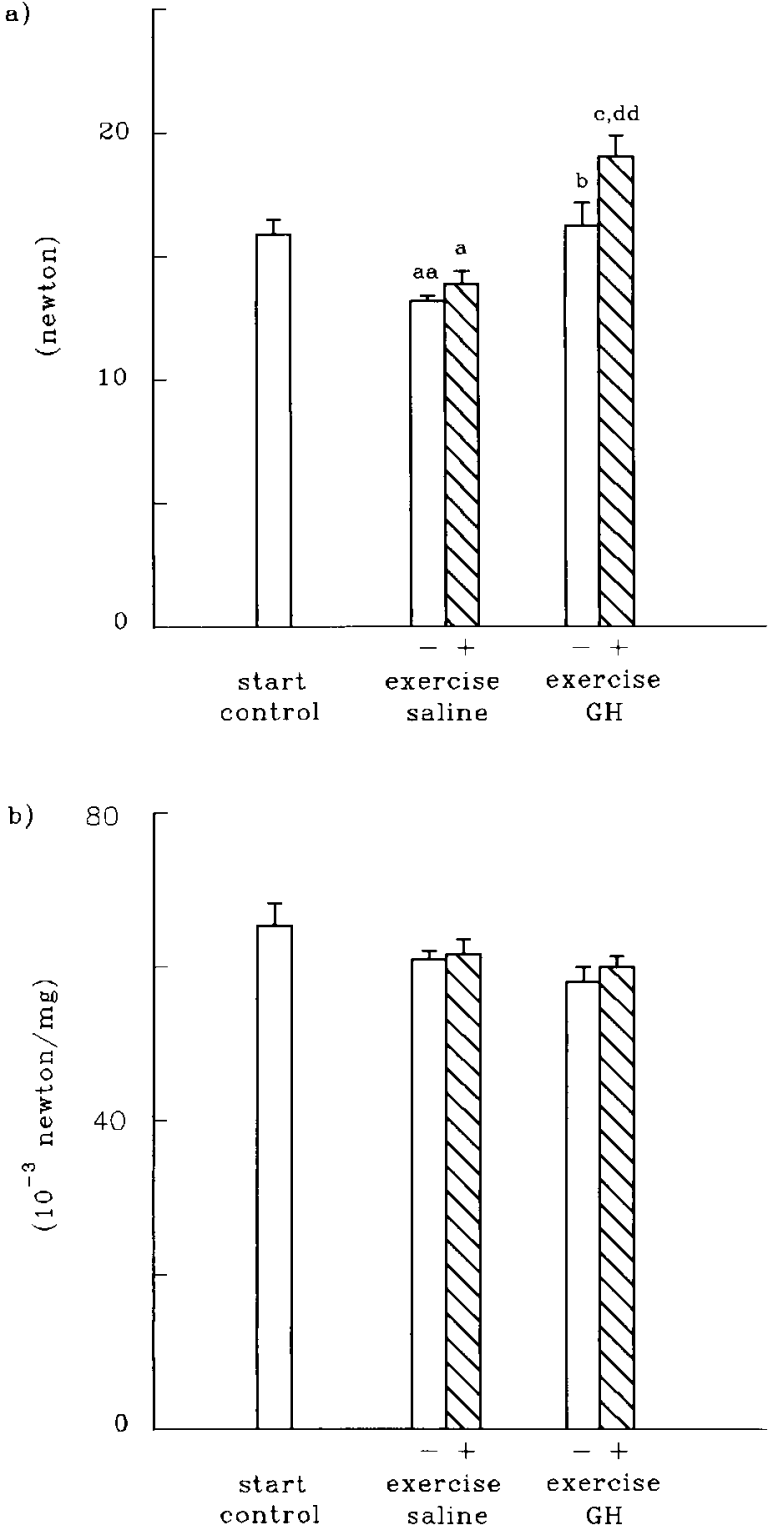

Figure 3 In vivo maximal tetanic tension (a) and maximal tetanic tension normalized to dry defatted weight (b) of calf musculature (m. soleus, m. plantaris, m. gastrocnemius) of old rats. Mean values with S.E.M. are given for the start control group, groups injected with saline, exercised, injected with growth hormone $(\mathrm{GH})$, and exercised+injected with $\mathrm{GH}$ daily for 73 days. Exercised groups are delineated by hatched bars, and groups without exercise by open bars. a, $P \leq 0.05$; aa, $P \leq 0.01$ against start control;

b, $P \leq 0.05$ against saline; dd, $P \leq 0.01$ against exercise;

c, $P \leq 0.05$ against $\mathrm{GH}$ alone.

compared with GH-injections alone was seen in $\mathrm{m}$. gastrocnemius. The four other muscles did not differ from those in the GH group (Table 1). There was a decrease in the hydroxyproline concentration in the $\mathrm{m}$. extensor digitorum longus (Table 3 ).

The maximal tetanic tension was $18 \%$ higher in the
GH-injected + exercised group compared to the group injected with $\mathrm{GH}$ alone. A clear correlation was found between the maximum tetanic tension and DDW of the calf musculature (Fig. 5, $r=0.80, P<0.00001$ ). A positive correlation was also observed between the DDW of the calf musculature and the body weight of the rats $(r=0.80, P<0.0001)$.

No difference was seen in maximal tetanic tension/ mg DDW or tetanic tension during $30 \mathrm{~s}$ of stimulation (Figs 3 and 4, Tables 2 and 4).

\section{Differences between the start control and the saline-injected group}

The serum IGF-I concentration was slightly reduced in the older saline-injected rats compared with the start control rats (Fig. 1b), and the muscle volume and DDW were decreased $(6-14 \%)$ in the saline-injected group compared to the start control group (Fig. 2).

The maximal tetanic tension decreased by $17 \%$ in the saline-injected group compared to the start control. No difference was found in the maximal tetanic tension $/ \mathrm{mg}$ DDW or time course of the tetanic tension (Figs 3 and 4, Tables 2 and 4).

\section{Discussion}

In these old female rats, $\mathrm{GH}$ administration increased the DDW and volume of skeletal muscles proportionately with the increase in body weight. Likewise, the maximal tetanic tension of the skeletal musculature increased proportionately to the increase in muscle mass in GH-injected rats; however, the muscle endurance (measured as tetanic tension during $30 \mathrm{~s}$ of stimulation) was unchanged after $\mathrm{GH}$ administration. The combination of $\mathrm{GH}$ administration + exercise resulted in a further increase in the muscle mass of $\mathrm{m}$. soleus and $\mathrm{m}$. gastrocnemius compared to the rats injected with GH alone, but no significant increase in muscle mass for $\mathrm{m}$. tibialis anterior, $\mathrm{m}$. extensor digitorum longus and $\mathrm{m}$. plantaris. The maximal tetanic tension of the calf musculature was correspondingly higher in the $\mathrm{GH}$-injected + exercised group than in the group injected with $\mathrm{GH}$ alone. Interactive effects of $\mathrm{GH}$ administration and exercise have been demonstrated on skeletal muscle mass; while exercise alone had minimal effects in maintaining the mass of unloaded muscles in hypophysectomized rats, there was a strong interaction effect of exercise and $\mathrm{GH}$ in combination, increasing muscle mass (7). In agreement with this, the combination of GH injections and exercise on hind limb suspended rats had greater effects on muscle protein synthesis than $\mathrm{GH}$ or exercise alone, and the loss of myofibrillar proteins was counteracted (8). Furthermore, GH/IGF-I and brief bouts of muscle loading have shown interactive effects in attenuating the loss of myonuclei induced by hindlimb suspension in rats (19), 
Table 4 Time course of tetanic tension during the first $30 \mathrm{~s}$ of stimulation. Tetanic tension is given as a percentage of the maximal tetanic tension.

\begin{tabular}{|c|c|c|c|c|c|c|}
\hline & A: Start control & B: Saline & C: GH & $\begin{array}{c}\text { D: Saline + } \\
\text { exercise }\end{array}$ & $\begin{array}{l}\text { E: GH + } \\
\text { exercise }\end{array}$ & $\begin{array}{l}\text { Kruskal- } \\
\text { Wallis } \\
P \text { value }\end{array}$ \\
\hline $\begin{array}{l}7.5 \mathrm{~s} \text { after stimulation }(\%) \\
15 \mathrm{~s} \text { after stimulation }(\%) \\
30 \mathrm{~s} \text { after stimulation }(\%)\end{array}$ & $\begin{array}{l}39 \pm 3 \\
14 \pm 2 \\
2.6 \pm 1.3\end{array}$ & $\begin{aligned} 43 & \pm 2 \\
12 & \pm 1 \\
-1.3 & \pm 1.0\end{aligned}$ & $\begin{array}{l}39 \pm 3 \\
15 \pm 2 \\
2.8 \pm 1.2\end{array}$ & $\begin{array}{l}42 \pm 3 \\
15 \pm 3 \\
1.4 \pm 1.4\end{array}$ & $\begin{array}{l}38 \pm 3 \\
13 \pm 2 \\
2.5 \pm 1.1\end{array}$ & $\begin{array}{l}P=0.654 \\
P=0.846 \\
P=0.100\end{array}$ \\
\hline
\end{tabular}

Means \pm S.E.M.

Saline, Saline injections; GH, Growth hormone injections

and ameliorates the apoptosis associated with hind limb unloading (20).

During the 73-day experimental period, the muscle mass of the saline-injected rats decreased significantly in 4 of 5 muscles, probably reflecting aging. The maximal tetanic tension decreased by $17 \%$ compared with the start control group. This is in agreement with the findings of previous investigations in old rats $(14$, $21,22)$. We found no changes in maximal tetanic tension/mg DDW, indicating that the reduced tetanic force in the saline-injected group compared to the start control group was related to the decrease in muscle mass. A slight reduction in the total number of muscle fibers was found in old rats (21). Another study (23) showed atrophy with aging of weight-bearing muscles containing type II fibers. Likewise, the decrease in muscle type IIA fibers with aging was found in humans (24). The close relationship between reduced muscle strength and reduced muscle mass in aging has been demonstrated in several studies $(25,26)$. The decrease in muscle mass has been associated with the decline in activity of the GH/IGF-I axis $(1,27)$.

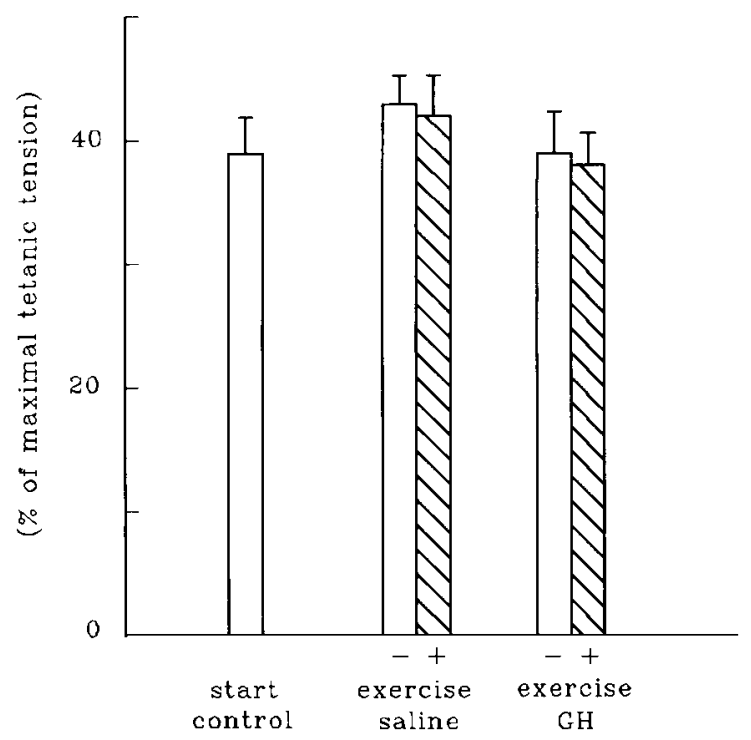

Figure 4 Tetanic tension of calf musculature after $7.5 \mathrm{~s}$ (\% of maximal tetanic tension). Mean values with S.E.M. are given.
Mild treadmill exercise was used in the present study as this mode of exercise could be applied similarly to a large number of rats. The mild exercise did not prevent the decrease in muscle mass and decrease in maximal tetanic tension except in $\mathrm{m}$. soleus, which maintained its weight and volume. This is in agreement with other studies which have shown that training regimens may increase type I muscle mass, but not type II, in old rats $(28,29)$, and increase the mitotic activity of satellite cells (30). Exercise may stimulate release of growth hormone $(31,32)$. Life-long physical training of rats resulted in increased concentration of the basement membrane collagens of skeletal muscles and preservation of muscle fiber type I (33).

The hydroxyproline concentration of $\mathrm{m}$. extensor digitorum longus in the $\mathrm{GH}$-injected rats was increased, in agreement with Ørtoft et al. (34).

The fat content of all calf skeletal muscles was markedly reduced in GH-injected rats. This is in agreement with several studies in humans demonstrating a decrease in the total fat content of the body

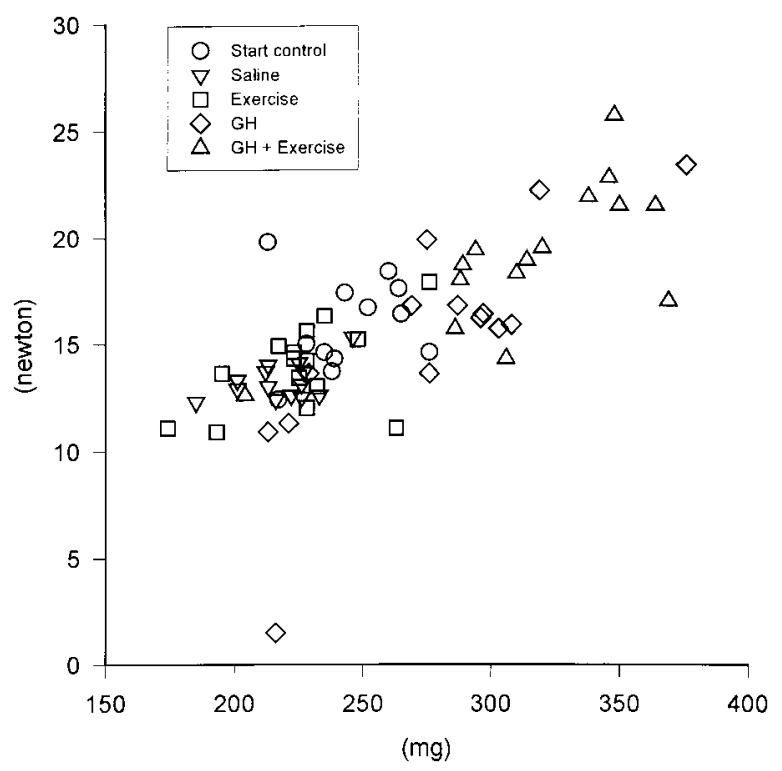

Figure 5 Relationship between maximal tetanic tension and dry defatted weight of the calf musculature. $r=0.80,2 P<0.00001$. 
after $\mathrm{GH}$ administration (1). The water content in all muscles was higher in $\mathrm{GH}$-injected rats than in salineinjected rats, but only in 3 of 5 muscles was a significant increase observed. The density $\left(\mathrm{mg} \mathrm{DDW} / \mathrm{mm}^{3}\right.$ ) was not influenced by $\mathrm{GH}$ administration, indicating that the quantity of contractile proteins per unit volume was not changed. The muscular density was highest in the $\mathrm{m}$. gastrocnemius and lowest in the $\mathrm{m}$. soleus.

Usually the values of maximal tetanic tension are normalized to the cross-sectional area of the muscles $(14,35,36)$. In the present study the cross-sectional area (as measured from histological sections) was not used for the normalization. GH injections induce pronounced alterations in muscle fat and water content of rats, which may influence the fixation of the muscular tissue, and certainly influence the measurement of the cross-sectional area of histological sections. We chose to measure the DDW, water content, fat content, volume of each muscle and the muscle density in order to determine the magnitude of these parameters. The DDW of the calf musculature was used for normalization of the maximal tetanic tension values, because the DDW reflects the skeletal muscle contractile proteins, and is independent of differences in fat and water content. Concerning maximal tetanic tension/mg DDW of the calf musculature, no difference between the groups was found, indicating that increases in DDW of the musculature induced by exercise and/or $\mathrm{GH}$ was closely associated with increased maximal tetanic tension. Maximal tetanic muscle tension/mg dry weight of the calf musculature expresses the ability of maximal tetanic muscle tension of the musculature regardless of muscle mass. In a previous experiment, (3), we found that $\mathrm{GH}$ induces an increase in the skeletal muscle mass of old Wistar rats. In the present study, we found that the maximal tetanic muscle tension increased correspondingly.

There was a systemic effect of the $\mathrm{GH}$ administration; the serum IGF-I concentration was increased twofold, the body weight of the rats was increased by $43 \%$, the DDW and volume of the muscles were increased by 25$50 \%$ compared to the saline-injected group, and the tibia lengths were increased by $6 \%$. These findings are in agreement with those of Cartee et al. (37). The maximal tetanic tension of the calf musculature was increased by $23 \%$ in the GH-injected rats corresponding to the increase in DDW. When GH and mild exercise were combined no further increase in body weight was observed. The DDW of the muscles was, however, increased by $41 \%$, and the maximal tetanic tension was increased by $44 \%$. Therefore, the GH administration induced a certain growth of the musculoskeletal system in these old rats. Exercise alone increased the muscle mass by $4 \%$ and maximal tetanic tension by $5 \%$, but these values were not statistically significant. When the exercise was combined with $\mathrm{GH}$, a substantial significant increase in muscle mass and muscle force was seen. The exercise procedure had to be mild in order to avoid stressing the rats and to ensure that they followed the exercise regimen.

Intense exercise and handling alone may result in a reduced GH secretion $(38,39)$. In the present study, the exercise procedure was rather mild and care was taken to avoid stressing the rats. The rats became tame and did not dislike the exercise. The exercise procedure did not change the concentration of serum IGF-I compared with the saline control group. The synergy of the effects of GH and exercise on muscle mass and maximal tetanic tension in the present study may be explained by exercise activating the muscle IGF-I pathway locally, acting in association with the systemic pathway of $\mathrm{GH}$ administration, even if exercise and handling of the rats have resulted in reduced $\mathrm{GH}$ secretion in other studies $(38,39)$. In adult rats there is low expression of IGF-I in skeletal muscles. After injury, however, the regeneration process is accompanied by marked increases in the levels of extracted IGF-I mRNA, and in situ hybridization studies on tissue sections show that IGF-I mRNA is expressed by regenerating muscle cells (40). Furthermore, IGF-I receptors are expressed in regenerating muscle cells (41). In hypophysectomized animals, high levels of IGF-I mRNA are also expressed after injury, indicating that IGF-I expression after skeletal muscle injury may be independent of GH (40). Therefore, IGF-I seems to be involved in muscle regeneration and growth, and IGF-I produced locally influences muscle cell growth via autocrine and paracrine mechanisms in concert with systemic IGF-I. The studies of Zanconato et al. (42) suggest that exercise results in both GHdependent increases in IGF-I mRNA in the liver and GHindependent increases locally in the muscles. In old mice, exercise increased the IGF-I receptor-binding capacity and affinity and stimulated protein synthesis (43), and adenoviral delivery of the IGF-I gene to skeletal muscles has been shown to increase muscle mass in old mice (44).

Rats injected with recombinant human GH develop antibodies after 23 days, as shown by Jørgensen et al. (45). The presence of antibodies does not, however, neutralize the $\mathrm{GH}$ or block the stimulating effects of $\mathrm{GH}$ on body weight gain, increase in serum IGF-I, or anabolic effects on bone and skeletal muscles.

In conclusion, we found that the increased muscle mass observed after GH injection is associated with a corresponding increase in maximal tetanic tension. The combination of $\mathrm{GH}$ injections + mild exercise increases the muscle mass and the maximal tetanic tension to a greater extent that $\mathrm{GH}$ injections and exercise alone.

\section{Acknowledgements}

We acknowledge Novo Nordisk A/S, The Danish Health Research Council, grants no. 9500922 (Centre for Molecular Gerontology), 9503023 and 9600822 (Aarhus University-Novo Nordisk Centre for Research in Growth and Regeneration), Aarhus University 
Research Foundation, Novo Nordisk Foundation. The authors are grateful to the Institute of Pathology, Aalborg Hospital, for animal care and exercising. The skilled technical assistance of E K Mikkelsen, K Nyborg, $\mathrm{N}$ Rosenquist and K Mathiessen, and linguistic revision of M Fischer are gratefully acknowledged.

\section{References}

1 Rudman D, Feller AG, Nagraj HS, Gergans GA, Lalitha PY Goldberg AF et al. Effects of human growth hormone in men over 60 years old. New England Journal of Medicine 1990323 1-6.

2 Welle S, Thornton C, Statt M \& McHenry B. Growth hormone increases muscle mass and strength, but does not rejuvenate myofibrillar protein synthesis in healthy subjects over 60 years old. Journal of Clinical Endocrinology and Metabolism 199681 3239-3243.

3 Andreassen TT, Jørgensen PH, Flyvbjerg A, Ørskov H \& Oxlund H. Growth hormone stimulates bone formation and strength of cortical bone in aged rats. Journal of Bone and Mineral Research $1995101057-1067$.

4 Carmeli E, Hochberg Z, Livne E, Lichtenstein I, Kestelboim C, Silbermann M et al. Effect of growth hormone on gastrocnemius muscle of aged rats after immobilization: biochemistry and morphology. Journal of Applied Physiology 199375 1529-1535.

5 Ullman M \& Oldfors A. Effects of growth hormone on skeletal muscle. I. Studies on normal adult rats. Acta Physiologica Scandinavica 1989135 531-536.

6 Florini JR \& Ewton DZ. Skeletal muscle fiber types and myosin ATPase activity do not change with age or growth hormone administration. Journal of Gerontology. Biological Sciences 198944 B110-B117.

7 Grindeland RE, Roy RR, Edgerton VR, Grossman VJ, Mukku VR, Jiang B et al. Interactive effects of growth hormone and exercise on muscle mass in suspended rats. American Journal of Physiology 1994267 R316-R322.

8 Linderman JK, Gosselink KL, Booth FW, Mukku VR \& Grindeland RE. Resistance exercise and growth hormone as countermeasures for skeletal muscle atrophy in hindlimb-suspended rats. American Journal of Physiology 1994267 R365-R371.

9 Deyssig R, Frisch H, Blum WF \& Waldhör T. Effect of growth hormone treatment on hormonal parameters, body composition and strength in athletes. Acta Endocrinologica 1993128 313-318.

10 Taaffe DR, Pruitt L, Reim J, Hintz RL, Butterfield G, Hoffman AR et al. Effect of recombinant human growth hormone on the muscle strength response to resistance exercise in elderly men. Journal of Clinical Endocrinology and Metabolism 199479 1361-1366.

11 Yarasheski KE, Zachwieja JJ, Campbell JA \& Bier DM. Effect of growth hormone and resistance exercise on muscle growth and strength in older men. American Journal of Physiology 1995268 E268-E276.

12 Yarasheski KE, Zachwieja JJ, Angelopoulos TJ \& Bier DM. Shortterm growth hormone treatment does not increase muscle protein synthesis in experienced weight lifters. Journal of Applied Physiology 199374 3073-3076.

13 Taaffe DR, Jin IH, Vu TH, Hoffman AR \& Marcus R. Lack of effect of recombinant human growth hormone $(\mathrm{GH})$ on muscle morphology and GH-insulin-like growth factor expression in resistance-trained elderly men. Journal of Clinical Endocrinology and Metabolism 199681 421-425.

14 Klitgaard H, Marc R, Brunet A, Vandewalle H \& Monod H. Contractile properties of old rat muscles: effect of increased use. Journal of Applied Physiology 198967 1401-1408.

15 Armstrong RB \& Phelps RO. Muscle fiber type composition of the rat hindlimb. American Journal of Anatomy $1984171259-272$.
16 Woessner JF. Determination of hydroxyproline in connective tissue. In The Methodology of Connective Tissue Research, pp 227-233. Ed DA Hall. Oxford: Joynson-Bruvvers, 1976.

17 Flyvbjerg A \& Ørskov H. Kidney tissue insulin-like growth factor I and initial renal growth in diabetic rats: relation to severity of diabetes. Acta Endocrinologica 1990122 374-378.

18 Sokal RR \& Rohlf FJ. Biometry. San Francisco: WH Freeman \& Co, 1981.

19 Allen DL, Linderman JK, Roy RR, Bigbee AJ, Grindeland RE, Mukku $\mathrm{V}$ et al. Apoptosis: a mechanism contributing to remodeling of skeletal muscle in response to hindlimb unweighting. American Journal of Physiology 1997273 C579-C587.

20 Allen DL, Linderman JK, Roy RR, Grindeland RE, Mukku V \& Edgerton VR. Growth hormone/IGF-I and/or resistive exercise maintains myonuclear number in hindlimb unweighted muscles. Journal of Applied Physiology 199783 1857-1861.

21 Ansved T \& Larsson L. Effects of ageing on enzyme-histochemical, morphometrical and contractile properties of the soleus muscle in the rat. Journal of the Neurological Sciences 198993 105-124.

22 Brown M \& Hasser EM. Complexity of age-related change in skeletal muscle. Journal of Gerontology. Biological Sciences 199651 B117-B123.

23 Holloszy JO, Chen M, Cartee GD \& Young JC. Skeletal muscle atrophy in old rats: differential changes in the three fiber types. Mechanisms of Ageing and Development 199160 199-213.

24 Jakobsson F, Borg K \& Edstrom L. Fibre-type composition, structure and cytoskeletal protein location of fibres in anterior tibial muscle. Comparison between young adults and physically active aged humans. Acta Neuropathologica $199080459-468$.

25 Faulkner JA, Brooks SV \& Zerba E. Skeletal muscle weakness and fatigue in old age: underlying mechanisms. Annual Review of Gerontology and Geriatrics $199010147-166$.

26 Young A, Stokes M \& Crowe M. The size and strength of the quadriceps muscles of old and young men. Clinical Physiology $19855145-154$.

27 Horber FF, Kohler SA, Lippuner K \& Jaeger P. Effect of regular physical training on age-associated alteration of body composition in men. European Journal of Clinical Investigation 199626 279-285.

28 Brown M, Ross TP \& Holloszy JO. Effects of ageing and exercise on soleus and extensor digitorum longus muscles of female rats. Mechanisms of Ageing and Development 199263 69-77.

29 Daw CK, Starnes JW \& White TP. Muscle atrophy and hypoplasia with aging: impact of training and food restriction. Journal of Applied Physiology $1988642428-2432$.

30 McCormick KM \& Thomas DP. Exercise-induced satellite cell activation in senescent soleus muscle. Journal of Applied Physiology $199272888-893$.

31 Kanaley JA, Weltman JD,Velhuis JD, Rogol AD, Hartman ML \& Weltman A. Human growth hormone response to repeated bouts of aerobic exercise. Journal of Applied Physiology 199783 1756-1761.

32 Roemmich JN \& Rogol AD. Exercise and growth hormone: does one affect the other? Journal of Pediatrics 1997131 S75-S80.

33 Kovanen V, Suominen H \& Peltonen L. Effects of aging and lifelong physical training on collagen in slow and fast skeletal muscle in rats. Cell and Tissue Research 1987248 247-255.

34 Ørtoft G, Kelly C, Brüel A, Smith A, Carter N \& Oxlund H. Glococorticoids inhibit the growth hormone induced increase in serum IGF-I and its mRNA, body weight and muscle mass of rats. European Journal of Experimental Musculoskeletal Research 19932 135-142.

35 Schluter JM \& Fitts RH. Shortening velocity and ATPase activity of rat skeletal muscle fiber: effects of endurance exercise training. American Journal of Physiology 1994266 C1699-C1673.

36 Widrick JJ, Romatowski JG, Karhanek M \& Fitts RH. Contractile properties of rat, rhesus monkey, and human type I muscle fiber. American Journal of Physiology 1997272 R34-R42. 
37 Cartee GD, Bohn EE,Gibson BT \& Farrar RP. Growth hormone supplementation increases skeletal muscle mass of old male Fischer 344/brown norway rats. Journal of Gerontology. Biological Sciences 1996 51A B214-B219.

38 Buktus JA, Brogan RS, Giustina A, Kastello G, Sothmann M \& Wehrenberg WB. Changes in the growth hormone axis due to exercise training in male and female rats: secretory and molecular responses. Endocrinology $19951362664-2670$.

39 Millard WJ, Romano TM \& Simpkins JW. Growth hormone and thyrotropin secretory profiles and provocative testing in aged rats. Neurobiology of Aging $199011229-235$.

40 Edwall D, Schalling M, Jennische E \& Norstedt G. Induction of insulin-like growth factor I messenger ribonucleic acid during regeneration of rat skeletal muscle. Endocrinology 1989124 820-825.

41 Jennische E. Sequential immunohistochemical expression of IGF-I and the transferrin receptor in regenerating rat muscle in vivo. Acta Endocrinologica 1989121 733-738.

42 Zanconato S, Moromisato DY, Moromisato MY, Woods J, Brasel JA, Leroith D et al. Effect of training and growth hormone suppression on insulin-like growth factor I mRNA in young rats. Journal of Applied Physiology 199476 2204-2209.

43 Willis PE, Chadan S, Baracos V \& Parkhouse WS. Acute exercise attenuates age-associated resistance to insulin-like growth factor I. American Journal of Physiology 1997272 E397-E404.

44 Barton-Davis ER, Shoturma DI, Musaro A, Rosenthal N \& Sweeney HL. Viral mediated expression of insulin-like growth factor I blocks the aging-related loss of skeletal muscle function. PNAS 199895 15603-15607.

45 Jørgensen KD, Svendsen O, Greenough RJ, Kallesen T, Goburdhun $\mathrm{R}$, Skydsgaard K et al. Biosynthetic human growth hormone: subchronic toxicity studies in rats and monkeys. Pharmacology and Toxicology 198862 329-333.

Received 4 November 1999

Accepted 12 May 2000 